\title{
The Study on Relationship between Gold and Oil - A General Perspective
}

\author{
Dr. S. Mahalingam¹, K. Perumal² \\ ${ }^{1}$ Professor, BSMED, ${ }^{2} \mathrm{Ph} . \mathrm{D}$ Research Scholar \\ Bharathiar University, Coimbatore, Tamil Nadu, India
}

\begin{abstract}
This article focus on "The Study on Relationship between Gold and Oil - A General Perspective" The aim of this article is to analyze and determine the character of the co-movement between price levels. This article also presents the basic characteristic and determinants of current price trends. The work uses methods of analysis and synthesis of theoretical knowledge from literature (Gold and Oil) published article and other publications. There is also included a quantitative analysis of the variable. This paper reveals the extreme of a long term relationship analyses variable.
\end{abstract}

KEYWORDS: Gold prices, inflation hedging, assets, time series econometric technique

\section{INTRODUCTION}

Today, gold, oil and also other commodities are predominantly quoted in U.S. Dollars. In relation to oil, major player is OPEC (The Organization of the Petroleum Exporting Countries), which formally agreed to sale its oil production exclusively in U.S. Dollars. In the case of gold it is important to mention that from 1944 to 1971, U.S. dollars were convertible into gold, in order to prevent any trade imbalances between countries. Then and there, price of gold was fixed at $\$ 35$ per troy ounce. Even the price of oil was relatively stable at around $\$ 3$ per barrel. After 1971, when the dollar convertibility into gold was can-celled, price stability of both researched commodities has disappeared, but despite the significant volatility in their price levels, kind of common trend can still be seen in their price development.

One way that investors like to track gold's relationship with crude is through the gold-oil ratio, indicating how many barrels of oil an ounce of gold will buy. This ratio is found by dividing the price of gold by oil's price. Historically-high ratios have occurred when gold was expensive relative to crude. Lower values were seen when gold was cheap compared with oil.

A trend of inter connectivity is evident in the commodity market with the most important ones being Gold and Crude oil. Gold is the oldest precious metal known to man, and it has been valued as a global currency, a commodity, an investment and an object of beauty. On the other hand crude oil is attributed as the "Mother of all commodities" because of its importance in the manufacturing of a wide variety of materials. The interconnection of the two commodities started in the year 1933, where the crude oil producers of Middle east demanded gold in return of crude oil. Today Gold and crude oil are predominantly quoted in US dollars. A theoretical and quantitative analysis is made to have an overview of relationship between gold and crude oil. The basic characteristics of products, its global and Indian scenario as well as the factors influencing the market are analyzed in this paper.

\section{Overview of Gold and Crude Oil Trade:}

The Schemes were to monetize the idle gold into economy and to satisfy never ending demand for gold by Indians, without actually holding physical gold. The government's decision to launch these schemes has the potential to translate gold savings into economic investments and make precious metal an integral part of financial system. The gold imports stood at $\$ 2.05$ billion in September 2015 (Source: Economic times). Crude oil is the complex mixture of various hydrocarbons found in the upper layers of earth's crust. Crude oil is often called the "Mother of Commodities" because of its importance in making wide variety of other commodities. Crude oil is used in the produce fuel for cars, buses, trucks, airplanes and trains. It is also used in using wide variety of other products like asphalt for roads, lubricants for all kinds of machines, plastics for toys, bottles etc among others. India is now the third largest importer of crude oil after United States and China

\section{Relationship between Gold and Crude Oil Prices}

The main idea behind the gold-oil relation is the one which suggests that prices of crude oil partly account for inflation. Increases in the price of oil result in increased prices of gasoline which is derived from oil. If gasoline is more expensive, than it's more costly to transport goods and their prices go up.

\section{Investing using Leverage:}

Bullish investors may choose to leverage their position by borrowing money against their existing gold assets and then purchasing more gold on account with the loaned funds. This technique is referred to as a carry trade. Leverage is also an integral part of buying gold derivatives and un-dged

\section{Is it the right Time to invest in Gold:}

Let us analyze various factors which affect price of gold and then decide whether it is the right time to invest in Gold.

\section{Dollar is quite weak -}

The dollar is falling against other major currencies because corporate earnings in the US has fallen and pointed to further weakness in the U.S. economy. The decline in the dollar helps boost gold, which is often used as a hedge against inflation and a weak US dollar, world's safest 
investment option. Due to this, Chinese have decided to decrease their exposure to US dollar. Also, China is thinking of boosting its gold reserves from 600 tonnes to nearer 4,000 tonnes to diversify away from paper currencies. This will further boost gold prices.

\section{Interest rate is quite low -}

With the deepening financial crisis and US economy into recession, interest rates in the US has almost come down to zero. It might have to struggle with deflation for some time. Thus, countries which are having surplus foreign exchange reserve will now not invest in US treasuries due to extremely low interest rates. This will force them to park their huge wealth in the other most important and safe asset - GOLD. This will lead to increase in demand for Gold and put upward pressure on its price.

\section{Check gold-to-oil ratio -}

In June 2008, the gold-to-oil ratio dipped to abysmal 7 which indicated that gold price was going to rise aggressively. Why? Technically speaking this is because oil price is going down due to lower demand and global recession. Thus, to maintain a historical ratio of between 12 and 14, the gold price has to go up to achieve this ratio. Theoretically speaking, with the lowering price of oil inflation will come down significantly and so the interest rates. This will make the option of keeping surplus reserve in bank unattractive. Hence, most of the investors and central banks will invest them in gold, which is by far the safest investment. However, if we look at the current value of ratio it is more than 20 indicating that sooner or later either oil prices will go up or gold prices come down to reach historical average number.

\section{Political uncertainty -}

The political crisis between Indian and Pakistan, Israel and Palestine war and America's growing impatience with Iran is creating political uncertainty across Asia and Middle-east. In the event of war like situation, investors prefer to park their money more into external resources. In this time of global recession, gold is again the best option for these investors. Thus, gold price will see upward price movement in the coming days.

\section{Global Meltdown -}

The major economies, US, UK, Japan and other rich EU countries are officially into recession due to unprecedented financial crisis. This has broken down investors' confidence in traditional financial instruments like stocks and bond. The general rule of thumb in the market is that gold is always attractive when all other investments are unattractive. Why is this? As gold is negatively co-related to stocks, bonds, and real estate, gold is considered to be a safe haven and hence during any crises, investors would like to sell off what they would term as risky investments and be invest the funds in gold. Investors often turn to gold in times of economic uncertainty because the yellow metal's value tends to hold up better than many other investments.

All these factors weigh heavily in favor of gold. Investors are these days really scared of stock markets (especially in emerging economies) and real estate. This leaves them with Gold as the safest and best option. If we assume that gold price increase in future, the gold-to-oil ratio will become even higher; it may cross an all time high of 40 . This may not justify the valuation theoretically but investors are hardly driven by intrinsic value and fundamentals. So you may expect further increase in the price of good in the coming months. It will probably touch $\$ 1800$ per ounce by the end of this year.

I believe the price of gold depends on how crude behaves in the future. The question to ask is whether this increase will be sustainable? I believe not in the long run. A lot depends on how global economy shapes up in the next couple of years. If there is marked improvement in global financial market, investors will again look for equities and bonds as an investment. However, till then gold will continue to glitter!

\section{How to Invest in Gold:}

Investment in gold can be done directly through ownership, or indirectly through certificates, accounts, spread betting, derivatives or shares.

\section{Gold Bars or Coins:}

Investment in gold should be either in gold coins or bars. However, it should always be bought from banks which certify the quality of gold. Moreover, only buy governmentcertified gold coins or bars and preferably the purity level should be 99.9 as they are easy to sell. The biggest drawback of this investment is either the risk of carrying them at home (an unsafe option) or pay the bank to store it. But are risky as well as expensive.

\section{Gold Certificates:}

A certificate which represents ownership of gold bullion held by a financial institution for convenient and safe storage. There is a fee for storage and insurance.

\section{Gold Futures:}

Gold contracts are the hottest commodities traded in the Indian market. It is traded on MCX (Multi Commodity Exchange) Gold has become the largest traded commodity in India's domestic futures market as a large number of traders are taking delivery of the yellow metals through the futures route.

\section{Gold ETFs:}

You may not be able to touch and feel your Yellow metal through ETFs, but they are perhaps the safest method of buying and owning gold. ETF stands for Exchange Traded Funds. These are generally open-ended funds i.e. they are traded on the exchange just like stocks. There are quite a few ETFs in the market namely- Reliance, Kotak, UTI Gold ETF to name a few.

\section{Jewelry -}

Buying jewelry is not the same as investing in gold because it is not made up from 24 carat gold as it is quite brittle. Moreover, when you sell jewelry some deductions are made to the jewelry because of its imperfection and age. Also, this is not as liquid as other pure gold related investments such as coins, bars and ETFs. However, investment in jewelry should be considered mostly as an emotional one!

The gold-oil ratio helps us to identify overbought and oversold opportunities for gold. The gold oil ratio expresses the interrelationship between the commodity that forms the foundation of our entire global economy and the commodity that has been the ultimate form of money for six thousand years of human history. 
Table below shows the average Gold-to-Oil ratio for the last year (monthly breakup data). We can see that the fall in oil price was much steeper than that of gold. Hence, the ratio actually increased after July 2008 and surpassed historical average of 14 in November. The last three year average for this ratio was about 17 . Does this mean gold is trading at its highest price level? Analysts disagree to it simply because the ratio is more of a long-term gauge and not on a month to month, year to year trend. Near-term price direction is difficult to predict trading the ratio.

Table

\begin{tabular}{|c|c|c|c|}
\hline Date & $\begin{array}{c}\text { Gold Price } \\
\text { (\$ per 0z) }\end{array}$ & $\begin{array}{c}\text { Oil Price } \\
\text { (\$ per barrel) }\end{array}$ & $\begin{array}{c}\text { Gold-to- } \\
\text { Oil Ratio }\end{array}$ \\
\hline Jan-08 & 889.60 & 84.70 & 10.50 \\
\hline Feb-08 & 922.30 & 86.64 & 10.65 \\
\hline Mar-08 & 968.43 & 96.87 & 10.00 \\
\hline Apr-08 & 909.70 & 104.31 & 8.72 \\
\hline May-08 & 888.66 & 117.40 & 7.57 \\
\hline Jun-08 & 889.49 & 126.33 & 7.04 \\
\hline Jul-08 & 939.77 & 126.16 & 7.45 \\
\hline Aug-08 & 839.02 & 108.46 & 7.74 \\
\hline Sep-08 & 829.93 & 96.13 & 8.63 \\
\hline Oct-08 & 806.62 & 68.50 & 11.78 \\
\hline Nov-08 & 760.86 & 49.29 & 15.44 \\
\hline Dec-08 & 816.09 & 32.94 & 24.78 \\
\hline Jan-09 & 858.69 & 37.20 & 23.08 \\
\hline
\end{tabular}

Source: IndianMoney.com Research

\section{Conclusion:}

From the study above it can be concluded that gold and crude oil have a positive correlation. Their inter relationship may be partly because of their valuation in US dollars, as both these commodities are quoted in US dollars in global market. If dollars weakens against rupee, imported items like oil, gold etc will cost more dollars. This may be the reason for their inter relation.

\section{Reference:}

[1] Ahmet B (2010) The Effect of Macroeconoics Variables on Stock Return: Evidence from Turkey. European Journal of Social Science.

[2] Basher SA, Sadorsky P (2006) Oil price risk and emerging stock markets. Globel Finance Journal 17: 224-251.

[3] Kwon CS, Shin TS (1999) Cointegration and Causality between Macroeconomic Variables and Stock Markets Returns. Globel Finance Journal 10: 71-81.

[4] Claire, Ginette, Rajneesh, Ahmet (2009) The Dynamics of Gold Prices, Gold Mining Stock prices and Stock Market Prices Comovements. Research in Applied Economics.

[5] Smith G (2001) The Price of Gold and Stock Price Indices for the United States. Adrienne Roberts FT Personal Finance.

[6] Handroyiannis G, Papapetrou E (2001) Macroeconomic Influences on the Stock Market. Journal of Economics and Finance 25: 33-49.

\section{Website:}

https://in.investing.com/commodities/crude-oil

www.googl.com

www.moneycontrol.com

www.investopedia.com

www.economictimes.com

https://www.bloombergquint.com 